\title{
Fantastic, Spirits, Pseudo-Science and Risorgimento in Nineteenth-Century Italian Narrative: The Case of Tarchetti's A Dead Man's Bone
}

\author{
Linda Garosi \\ Department of Language Sciences, Faculty of Philosophy and Literature, University of Córdoba, Spain
}

Received February 24, 2020; Revised April 9, 2020; Accepted April 27, 2020

Copyright $\bigcirc 2020$ by authors, all rights reserved. Authors agree that this article remains permanently open access under the terms of the Creative Commons Attribution License 4.0 International License

\begin{abstract}
This paper aims to study the Italian ghost story entitled A Dead Man's Bone, included in Tarchetti's Fantastic Tales (1869) to illustrate, by means of this specific case, both the way and the purpose of the reception of the Gothic and Fantastic in Italian narrative. For this reason, it is necessary to frame the textual analysis within the historical and cultural coordinates of the post-Unification years, in order to, first of all, clarify the fact that the operation ought to be evaluated in a specific ideological and compositional context rather than from a thematic point of view. In this regard, the study of $A$ Dead Man's Bone intends to highlight that the most relevant outcomes of Tarchetti's rewriting of a ghost story by Théophile Gautier have to be appreciated as the opening for new experiments in narrative forms which root in a rapidly changing situation and, nurtured by the disillusionment of the post-unification years. Moreover, the author's use of codes and conventions of a specific subgenre of modern Fantastic, such as the ghost story, is also related with his direct involvement in pseudoscientific movements as Mesmerism and Spiritism. It goes without saying that the author's effort to innovate narrative forms is meant to convey a personal interpretation of the present by means of a new kind of realism in art.
\end{abstract}

Keywords Tarchetti, Milanese Scapigliatura, Short Story, Ghost Story

\section{Introduction}

Igino Ugo Tarchetti's ${ }^{1}$ five short stories, posthumously

1 Igino Ugo Tarchetti (1839-1869) was born into a bourgeois family from the Italian region of Piedmont. He began his military career in the army of the newly unified Kingdom of Italy and fought against the brigantaggio in Southern Italy. In 1865 he settled in Milan, where he began to write for issued in 1869 by the Milanese publishing house Treves as Fantastic Tales (Racconti fantastici) [1], have been considered the first example of Fantastic in Italian narrative tradition; Vincenzo Moretti [2] points out that: "Prima della pubblicazione dei Racconti fantastici tarchettiani è arduo trovare nella letteratura italiana dell'Ottocento quei temi definiti dal Todorov tipici del genere fantastique: la metamorfosi, il pandeterminismo, la doppia personalità, il reciproco passaggio dalla materia allo spirito, le mistioni di tempi e di spazi lontani, le perversioni sessuali fino al vampirismo e alla necrofilia" (p. 17). He turns out to be the first Italian writer engaged with Fantastic and Gothic stories, or at least, as Neuro Bonifazi [3] states, "il primo frammentario ed estemporaneo sperimentatore" (p. 79). In the very introduction to his translation of Fantastic Tales, Lawrence Venuti [4] underlines that Tarchetti "was in fact the first practitioner of the Gothic tale in Italy, and most of his Fantastic narratives are based on specific texts by writers like Hoffmann, Poe, Nerval, Gautier, and Erckmann-Chatrian" (p. 9). ${ }^{2}$

The titles of the stories, which the young Tarchetti wrote between 1867 and 1868, - The Fated (I fatali), The Legends of the Black Castle (Le leggende del castello nero), The Letter U. Manuscript of a Madman (La lettera $U$. Manoscritto d'un pazzo), A Dead Man's Bone (Un osso di un morto) and $A$ Spirit in a Raspberry (Uno spirito in un lampone) - clearly indicate that the tales belong to a specific literary subgenre. Tarchetti is openly inspired by a narrative vein that had become quite fashionable in the

several newspapers, and became involved in the original Scapigliatura group. Typhus and tuberculosis led him to an early death in 1869. A poet and novelist, Tarchetti's prose works included Paolina (1865), Una nobile follia (1866-67), Fosca (1869), Racconti fantastici (1869), Storia di una gamba (1869), and the trilogy Amore nell'arte (1869).

2 Gaetano Mariani [5] identifies many of the foreign authors on which Tarchetti's fantastic tales are based. For both this question and others related with Scapigliatura, Mariani's essay remains an essential source. 
twilight of European Romanticis ${ }^{3}$. However, the outcomes of his assimilation and rewriting process are quite far from the pathos, suspense, and suspension of disbelief achieved by his masters, so much so that Ceserani [6] referred to his work with the neologism "racconti fantasticizzati". According to Umberto Bosco [7], Tarchetti fails to transmit "questo brivido di terrore come un Poe o un Hoffmann, a darci il senso dell'ossessione misteriosa" while the reader "non è trascinato a sentire che, una volta partiti da certe premesse, tutto si svolge ineluttabilmente. Si resta ai margini" (p. 135). For Enrico Ghidetti [8], Tarchetti's discursive practices and results border on plagiarism, since they were "opera di calco e intarsio" (p. 214). ${ }^{4}$ As a matter of fact, Tarchetti's adaptation of foreign material to the Italian tradition was often unsuccessful in molding it into new, and above all original, compositional solutions. In contrast, extensive analyses by more recent critics, far from rejecting these "racconti fantasticizzati" as not pure fantastic or gothic tales, have highlighted that the intrinsic value of Tarchetti's work should be understood and assessed in relation to the specific context in which it originated and the suitable narratological tools that were appropriate to portraying it. It is worthwhile to stress here that the opening for experiments in a new kind of realism was vaguely announced in his first programmatic essay, Idee minime sul romanzo (1865), where it was also recommended to resort to European models. Only a couple of years later, he expanded his ideas melting them with the conventions of Fantastic and Gothic together with his growing interest for parapsychology and the supernatural as it is evident in another decisive text. The preface of Riccardo Waitzen (1867) represented the fundamental turning point in the author's narrative search that, finally, culminated in the Fantastic Tales. Mariani [5] explains that: "Tarchetti, scegliendo la letteratura del fantastico, dava un deciso orientamento a quella sete di opposte esperienze [...] che caratterizza soprattutto il suo noviziato letterario [...] Partito difatti dalle posizioni del magico puro con l'Elixir dell'immortalità, progressivamente egli accoglie nella sua nozione di fantastico le indicazioni che gli venivano offerte dai numerosi racconti che andavano diffondendosi in Francia dopo il 1850 nel tentativo di conciliare la scienza col soprannaturale" (pp. 394-395).

Thus, to appreciate the scope and original contributions to the Fantastic in Italy by the hand of Tarchetti, it is

3 In this regard it is important to emphasize, in line with Franco Moretti [9], that the same books were read throughout Europe. The transnational circulation and translations of these texts attest to the success of popular novels, among them fantastic and gothic tales: "è un disegno regolare, quasi monotono: tutta Europa legge gli stessi libri, con lo stesso accanimento, e più o meno negli stessi anni (quando non mesi). Tutta Europa, cioè, si riconosce, non nel "realismo" (basta un'occhiata alla fortuna di Stendhal e Balzac, per capire come stiano le cose) -, ma in quella che Peter Brooks ha chiamato 'immaginazione melodrammatica': una retorica delle tinte forti, che mescola storia, emozioni e mistero, e viene perfezionata (oltre che da Verdi) da Dumas e Sue, i due scrittori più popolari dell'epoca" (pp. 180-181).

4 The essay was published in the Milanese Rivista Minima (October 1865) directed by Tarchetti's close friend, Salvatore Farina. necessary to frame his last tales within the historical and cultural coordinates of his time. The well-known Tarchetti's working method ought to be evaluated in a specific ideological and cultural moment rather than from a thematic point of view.

\section{Cultural Background}

\subsection{The Origin and Meaning of Gothic and Fantastic in Italian Literature}

While, as it is known, in Northern Europe and America, Gothic and Fantastic had flourished in the eighteenth and nineteenth centuries, achieving a great vitality in both popular fiction and high culture, they were only introduced in Italy until the decades following Italian Unification (1861). As Ceserani [10] argues, the appropriation of foreign texts, initially by the Scapigliati (literally, "the Disheveled"), is a crucial component of the introduction of the Gothic and Fantastic in Italy: "Drawing as they did almost entirely on French texts, the Fantastic appeared in Italy in the second half of the nineteenth century centered on the Piedmontese and Milanese Scapigliatura" (p. 42). Théophile Gautier, Edgar Allan Poe and E. T. A. Hoffmann, above all, inspired the major figures of the first Italian avant-garde movement active in protoindustrial and protometropolitan Milan; ${ }^{5}$ among them most of all Igino Ugo Tarchetti, but also Arrigo Boito and Emilio Praga, assimilated motifs as well as stylistic solutions for new experiments in narrative form. As a consequence, indeed there are no "pure" fantastic texts as such in nineteenth Italian narrative as mainly Bonifazi [3], Farnetti [11] or Desideri [12]'s essays unquestionably point out. Lugnani [13] maintains that what was more innovative in the birth of the Fantastic was the narrative mode, rather than its new content. Thus, far from questioning the existence of an Italian tradition of the Fantastic, it is worthwhile to take into account, with Billiani [14], its transnational character rooted in a critical junctures to understand that these: "Italian writers adopted the fictional models provided by foreign gothic and fantastic narrative traditions with the intent of subverting current literary paradigms, especially those proposed by realist narration" (p. 15).

While writers meant both undermine the national narrative space by pursuing fantastic and gothic models, and reconfigure the relationship between literature and

5 There is a vast literary bibliography in this regard. For a comprehensive study of the reception of North European Gothic and Fantastic in Italy see David Del Principe, Rebellion, Death and Aesthetics in Italy. The Demons of Scapigliatura, Fairleigh Dickinson University Press Madison, 1996; M. Farnetti. "Patologie del romanticismo. Il gotico e il fantastico fra l'Italia e l'Europa" in Mappe della letteratura europea e mediterranea, ed. G. M. Anselmi, Mondadori, Milano, 2002, 340-360; Ermanno Paccagnini, "Riprese gotiche nella narrative scapigliata", in Neogotico tricolore. Letteratura e altro, ed. E. Biffi Gentili, Fondazione Cassa di Risparmio di Cuneo, Cuneo, 2015, 49-64. 
reality, they also provided themselves with instruments to subvert bourgeois and capitalistic ideology as well as the centralism and authoritarism of the Savoy governement. It is legitimate to assume that the first Italian literary experiments with fantastic conventions and gothic themes might be considered metaphors of the difficulties and anxiety experienced by both the middle class and the intellectuals of the new Italy, which express, at the close of an historical cycle, the existing gap between their Risorgimento ideals and the arduous socioeconomic conditions of a country that was witnessing the beginnings of modernization. By means of mixing elements borrowed from the Gothic and Fantastic with those from historical realism, Italian writers experimented with narrative forms from which emerge: "un senso d'ambivalenza, etica e gnoseologica, nei confronti di una realtà politica e sociale rivelatasi ben altra -insoddisfacente - rispetto alle prospettive palingenetiche annunciate dal Risorgimento", as Billiani [15] observes. Nevertheless, but not opposite to this guideline, it is worthwhile to highlight, with Tellini [16], the forms and the extent of this process of reception: "il genere si diffonde non già come vittoria del favoloso e del fiabesco, su uno sfondo evanescente e tenebroso propizio all'apparizione dell'incredibile, ma come inaspettata epifania del mistero nella normalità delle abitudini quotidiane, tra le pareti domestiche" (pp. 119-120). ${ }^{6}$ The point is that the themes and narrative modes imported from European gothic repertoires were connected with a cultural background dominated by positivism rather than romanticism. In the late nineteenth century, writers employed Fantastic and Gothic, and above them all mainly Tarchetti, attracted by scientific points at issue in that moment. As a matter of fact, Tellini [16] notes that: "lo sviluppo del fantastico in area postunitaria, tra ricerca positiva e fiducia tecnologica, fa sì che esso si caratterizzi in senso realistico e si insinui nei “campi della realtà'." (p. 119). Lo Castro [17] explains that Scapigliati writers pretended to overcome the contraposition between two irreconcilable levels of reality (natural/supernatural, rational/irrational, possible/impossible), the field of science and that of art, and they tried to find a narrative mode that, by connecting them, aimed at forging a new concept of realism and a gnoseological dimension in art: "forte è in alcuni autori, che più di altri lo hanno praticato, la tendenza a servirsene in un orizzonte teorico di discussione della scienza (Tarchetti e Capuana soprattutto [...]). Per questa via pare che l'orizzonte fantastico sia disegnato piuttosto nell'ambito dell'interesse per i possibili territori non ancora esplorati o chiariti dall'indagine scientifica; per la

6 In the same line, Amigoni [18] observes that the scapigliati fantastic and gothic short stories are part of a "fantastico privo di truculenze e di mostri, [...] un fantastico domestico, minimale, in cui l'anomalia irrompe tra $\mathrm{i}$ tavolini da caffé degli intellettuali squattrinati e i cortili delle case popolari, mentre l'autore è privo di quella superiorità o sicurezza di voce che i narratori inglesi o francesi non perdono neppure quando pongono i loro personaggi davanti ai fenomeni meno controllabili” (p. 39). capacità del reale di comprendere un orizzonte più vasto di quello strettamente spiegabile con le leggi della scienza; o, semplicemente, per mettere quasi periodicamente alla berlina il rigore ottuso dello scienziato che rifiuta ciò che sfugge alla sua tecnica" (p. 7).

Nevertheless, the predilection for the great masters of the fantastic, which arose from a desire to rejuvenate the Italian literary scene, was established by means of sub-cultural phenomena, such as Spiritism and Mesmerism (or Magnetism), which had gained enormous popularity in the period concerned. They were heterogeneous and contradictory instances verging on syncretism and characterized by an inherent ambiguity, which the narrative codes and structures of the fantastic capitalized upon. Gallini explains [19] that: "l'indagine soprannaturale, alla quale venivano paradossalmente asserviti i metodi offerti dalla scienza moderna, era divenuta una consuetudine nel contesto della seconda metà dell'Ottocento, e un ambito a cui attinsero in particolar modo gli artisti e gli scrittori tra fine Ottocento e Novecento" (p. 23). As a result, Mesmerism first and Spiritism then should be taken into account as sources of metaphors and terminology useful to authors who pretended to depict reality and the self in a way different from realistic and historical novel tradition.

\subsection{Tarchetti's Interest in Mesmerism and Spiritism}

In this context, it was not by chance that the introduction of Fantastic and Gothic in Italy coincided with the widespread first of Mesmerims (or Animal Magnetism) and then of Spiritism. As Gallini [19] stresses, the revival of a widespread interest for supernatural as well as for parapsychology in an age of enthusiastic faith in science and particularly in medical science, achieved a great cultural significance if we consider it as a part of the search for national identity in the post-unification Italy, mainly forged in the heart of two modern cities like Milan and Turin. Although this pseudoscientific movement failed to materialize in a coherent and comprehensive conceptualization, indeed it achieved a deep and wide relevance impact in nineteenth-century society, as Gallini [19] or Cigliana [20] underline from the cultural anthropology perspective. The points at issue here are that, first, in post-unification Italy, the real cultural background was undeniably more heterogeneous than official history depicted it, and second that the connections between scientific method and the supernatural world were usual at that time. In the same years that the young Tarchetti began to write poetry, tales and novels, the first Italian major spiritualist journal, Annali dello Spiritismo (Annals of Spiritism), appeared in Turin, the capital of the newly proclaimed Kingdom of Italy. First published in 1864 under the direction of Teofilo Coreni, the Annali featured reports on cases of spiritism occurring in Italy and Europe. To concur with Vincenzo Moretti, Tarchetti was probably 
familiar with the journal and its contents as it circulated in the circles of its closest followers. In addition, as Moretti explains [2], the publication may also have influenced Tarchetti's vague epistemic configuration, for, beyond reporting news items on Spiritism, in the Annals, "la professione di spiritismo non si presenta come un mero atto di fede, ma si preoccupa di trovare fondamenti filosofici e ideologici" (p. 21). Another publication of the same period, L'epoca nuova (The New Age), viewed Spiritism as a bulwark against a growing skepticism deemed as being devoid of ideals. In a long and obscure article titled "Spiritismo e Materialismo" ("Spiritism and Materialism"), the director of the Annali set forth a series of ideas and elements that, though somewhat muddled, provide an interesting key to understanding Tarchetti's mediation. In the article, Coreni presents the new belief as being superior to the blind faith of religion grounded in a paradoxical mixture of fideism and positivist thinking that rejects the materialism at the root of both contemporary economic liberalism and socialist and democratic institutions, or at least their more radical and subversive tendencies. In this regard, Vincenzo Moretti [2] notes that: "Tarchetti scrive i suoi Racconti fantastici, dove si danno molti elementi riportabili, anche se non direttamente, alla sottocultura espressa dalle citate riviste: dal totale disinteresse per la religione tradizionale alla curiosità per il Positivismo, all'attrazione per lo spiritismo alla sfiducia nelle illusioni socialiste, che avevano ispirato il 'romanzo sociale' Paolina, oppure negli ideali risorgimentali alla cui demistificazione il Nostro potentemente contribuì con i Drammi di vita militare. Ma in Tarchetti gli elementi sottoculturali dello spiritismo alla moda si uniscono e si confondono con l'istanza culturale di sperimentare un nuovo genere nelle sue canoniche tematiche, rielaborate tuttavia mediante personali moduli strategici e stilistici" (p. 22). As we can see in the long introduction to Riccardo Waitzen (1867), Tarchetti [21] discusses the issues raised by Mesmerism and Spiritism, aiming for fixing a different paradigm for reality and truth to be literary recreated. To this regard, before focussing on the prologue of the story, it's interesting for our purpose recollecting Salvatore Farina's witness. In fact, in the same year, Farina [22] was introduced by his close friend Tarchetti to animal magnetism: "Già Ugo a Torino mi aveva iniziato al magnetismo animale; assistendo ai passi con i quali egli addormentava sua sorella Amalia, udendo le risposte stranissime della veggente, certo avevamo strappato un lembo di quel mistero che non pareva dovesse lungamente nasconder la verità a noi cara" (pp. 162-163).

In similar terms, at the beginning of Riccardo Waitzen, Tarchetti [21] describes Mesmer's discovery showing his concern about what science might have to say about extra-sensible reality and about its relationship with Spiritism: "Ma la scienza ha pure rialzato in questi ultimi tempi un lembo della cortina misteriosa. Mesmer, colla scoperta del magnetismo, sembrò aver fatto un passo gigantesco su questa via. I primi fenomeni di quella scienza, arcani, oscuri, confusi, perciò accolti con quella superstiziosa incredulità che affascina tutti gli uomini all'idea dell'incomprensibile e dello ignoto, sembrarono aver afferrato le prime fila per districare tutto quanto il segreto, fino allora inviolato, della natura umana: la fusione delle anime, la trasmissione del pensiero, la chiaroveggenza, l'intuizione, l'unificazione di due, di più individualità, furono altrettante scoperte che parvero assicurarci la conquista di verità prodigiose e infinite" ( $\mathrm{p}$. 600).

As Farina [22] recalls, Tarchetti's first excitement on being introduced to Magnetism turned into disappointment which, in the meanwhile, was accompanied by a developing interest in Spiritism itself: "Fu meglio quando T. mi mandó La pluralité des mondes habités dove, saltando ogni barriera scientifica, Camille Flammarion ci assicura che l'uomo non è la prima né l'ultima incarnazione dello spirito pensante. Eravamo dunque preparati alla nuova parola, ma volevamo che questo verbo ci fosse confermato dalla scienza ufficiale" (pp. 162-163). The search for supernatural as the expression of authentic reality, as well as his efforts to untie material world and paranormal, bring Tarchetti to sounding parapsychic phenomena while provides him the opening for new experiments in form. From The Elixir of Immortality to Riccardo Waitzen and finally to Fantastic Tales, Tarchetti [21]'s rewriting and adaptation of gothic themes and fantastic conventions à la mode becomes more functional to create a "poetica illusione" aiming to "mettere in rapporto il mondo fisico col mondo spirituale" through spiritualist doctrines, since he defines it as "questa applicazione singolare della scienza" (p. 601). In fact, Tarchetti's more successful fantastic and gothic short stories move from his interest in the supernatural and parapsychology grounded in a specific, as well as heterogenous, cultural context where the edges between Science and Spiritism were frequently blurred. On this matter, Gallini [19] observes that: "nello spiritismo confluiscono molti elementi culturali di origine arcaica l'evocazione degli spiriti dei defunti, le case infestate, ecc.- ma già la sua pretesa di dimostrazione 'scientificamente', 'sperimentalmente' l'esistenza dell'oltretomba ne fa un fenomeno nuovo e diverso, che radicalizza posizioni già anticipate nel magnetismo. Di tanto più problematico, se si pensa che la cultura (egemonica?) positivistica fu largamente interessata allo studio anche dei fenomeni spiritici” (p. 210). In general, it could be repeated here that the reception of European Fantastic and Gothic carried out by Scapigliati ought to be framed into a specific cultural situation which Giovanna Rosa [23] portrays as a "clima positivista dominato dallo scontro fra spiegazioni razionali, condotte in nome delle nuove discipline scientifiche (magnetismo, mesmerismo, 
ipnotismo) e la fascinazione artistica per i misteri insondabili" (p. 87). ${ }^{7}$

\section{Tarchetti's Fantastic Tales}

It is important to refer here what Tarchetti [1] writes in the preface to The Fated. That is the opening text of the volume Fantastic Tales. By means of relating a story of jettatura, he couldn't but recognize the undeniable as well as inexplicable relation between the spiritual world and the material one: "la scienza ha analizzato la natura; i suoi sistemi, le sue leggi, le sue influenze ci sono quasi note: ma essa si è arrestata dinanzi ai fenomeni psicologici, e dinanzi ai rapporti che congiungono questi a quelli. Essa non ha potuto avanzarsi di più, e ha trattenuto le nostre credenze sulla soglia di questo regno inesplorato. Poiché nell'ordine dei fatti noi possiamo ammettere delle tesi generali, delle verità complesse; non nell'ordine delle idee" (p. 8). In Tarchetti's Fantastic Tales, the unknown and irrational are manifested according to their multiple possibilities: the plot of The Fated revolves around the sinister influence of certain people, The Letter $U$ speaks of madness, A Spirit in a Raspberry deals with a case of transmigration, while The Legends of the Black Castle and A Dead Man's Bone are about spiritism, ghosts, immaterial entities and other paranormal phenomena. In recalling the ideological underpinnings that operate in Tarchetti's adaptation and rewriting, it is should be emphasized that he considered paranormal phenomena to be inherent to normal everyday life, hence an intrinsic part of reality, and for this reason he pointed out that his stories were rooted in an oxymoron, since they strove to represent a more authentic, higher reality. In regard to the kind of fantastic mode Tarchetti chose and developed on the basis of his specific interests and purposes, Gaetano Mariani [5] has explained that: "siamo già nel vivo di quella ricerca del magico naturale, del soprannaturale come espressione della realtà quotidiana che Tarchetti si propone di raggiungere in molti suoi racconti” (p. 398). In the same line, Pieri [24] remarks that by these short stories "Tarchetti tenta una rivoluzione copernicana all'interno del fantastico ottocentesco: spostarlo sul terreno della narrazione realista; il più idoneo per fare del mondo fantastico uno strumento scientifico di analisi scrutante con occhio oggettivo gli sconosciuti principi immateriali attivi fra le segrete pieghe del mondo. Così la realtà naturale non è disgiunta da quella soprannaturale; va solo conosciuta attraverso la scienza della letteratura" (p. X). From this point of view, "l'atteggiamento obiettivo di osservatore" (p. 135) stressed by Bosco [7] with which Tarchetti focuses on the cases he recounts, comes together with the effort to build an effect

7 To deepen into this issue, see also Annamaria Cavalli, La scienza del romanzo. Romanzo e cultura tra Ottocento e Novecento, Pàtron, Bologna, 1982. of verisimilitude that plays a fundamental part in order to create the illusion of reality. As it is said by Emanuela Scarano [25] narrative fantastic mode must pivot around an articulated and subtle strategy for "autenticazione" of the real. In this line, Mangini [26] explains that the Fantastic Tales ought to be reconsidered as the first and fully aware "sperimentazione in terra italiana di un modo narrativo che fa della quotidianità lo schermo su cui proiettare con la maggior nettezza i pallidi fantasmi della psiche, e che usa l'ingannevole oggettività dello stile come strumento accuminato a forzare le malchiuse porte che separano il mondo della veglia da quello dell'incubo" (p. 94). Concerning Tarchetti's formal narrative solutions, Pieri [27] rightly states that the author "non ambisce a costruire ad arte una drammatica dell'ignoto ma la sua rivoluzionata grammatica" (p. 117). It should be stressed that the scientific (or pseudo-scientific) perspective of the stories is conveyed by means of a narration voice pretending to be objective. The contrast between the true and the possible, appearance and reality, "mondo spirituale" e "mondo fisico" are conflated to create a diegetic unicum through the mediation of the principal character who, in turn, plays the role of an impartial narrator. In addition, by the use of prefaces Tarchetti presents the story as an experience truly lived firsthand. These procedures make the reader recognize the paranormal events recounted as authentic. Finally, what creates the effect of estrangement in the reader is not only the strange case which disrupt the natural order of things, but the vision of a disquieting present, that of Italian society in post-unification years, reassembled by a disjointed subjectivity deprived of power. Thus, the narration itself is not, according to Pieri [27], a "felice risultato della mediazione fantastica, ma come il frutto di un'allarmante realtà" (p. 116). Once more with this scholar [27] it is important to underline that in Tarchetti "permane forte la convinzione che il criterio di valore di un racconto fantastico non è dato da un'astratta allucinazione di eventi dosati ad arte, ma da un'incrinatura interna alla coscienza dell'uomo reale, del quale il racconto è lo specchio fedele" (p. 123). As a consequence of this, it can be stated that the Fantastic Tales are the most outstanding outcome of Tarchetti's experimentation in the fantastic mode. He was able to shape an original narration form where his programmatic ideas and compositional innovations adhered together.

\section{A Dead Man's Bone: Tarchetti Ghost Story}

Among Tarchetti's Fantastic Tales, there are three in which he explicitly treats parapsychological phenomena: $A$ Spirit in a Raspberry, The Legends of the Black Castle and A Dead Man's Bone. In this last one, a semiserious ghost story is staged. It pretends to be trusted as a real event happened to the character-narrator. The synchronization 
and integration of elements borrowed from Gothic and Fantastic within the cultural coordinates of the author's time, together with his effort to innovate narrative, are exemplified in the specific case of the text A Dead Man's Bone.

In this ghost story the effect of reality is achieved by means of a convention typical of nineteenth-century narrative: the homodiegetic confession of a narrator which is the main character. The author appears to identify himself with the narrator-protagonist, thus attenuating the deviation between the real and the fictional and establishing the paradigm of reality. In addition, the gothic elements and paranormal events are woven together in a narrative form which is part of a scientific approach, whose distinctive rhetorical feature is the impartiality with which the protagonist (an intra- and homodiegetic narrator) refers, at first hand, to the extraordinary events he has witnessed. The objective description of these exceptional events permits the reader to interpret them freely and even choose to believe them or not. Indeed, as the narrator explains, "Lascio a chi mi legge l'apprezzamento del fatto inesplicabile che sto per raccontare" (p. 65).

Before describing the paranormal events, the narrator provides the reader with background elements by recalling that in 1855 , as a young art student, probably in a fine arts academy, the protagonist met the renowned professor Federico M. in the city of Pavia in northern Italy. ${ }^{8}$ The professor invites him to attend his anatomy classes, claiming that they would allow him to improve his art technique. The young man asks the professor to give him some bones from the corpses he dissects during his lectures. Shortly after, the professor dies, and the aspiring painter abandons his studies. However, for several years he preserves the scientific 'relics' that the professor has given him. Having come to fear the bones, he decides to bury all of them but one: a kneecap. As in Théophile Gautier's The Mummy's Foot [28], whose narrative scheme Tarchetti drew from, as Mariani [5] demonstrates, the narrator keeps the bone on his desk to use it as a paperweight, until it inexplicably disappears. After settling in Milan some eleven years later," the hero meets a hypnotist: "Avevo conosciuto a Milano nella scorsa primavera un magnetizzatore assai noto tra gli amatori di spiritismo, e aveva fatto istanze per essere ammesso ad una delle sue sedute spiritiche" (p. 66). Piqued by his curiosity, and despite his wariness, he asks to take part in a séance in order to invoke the professor's spirit and learn his scientific opinion about the fate of humanity and the spiritual dimension of human nature. However, when the spirit appears in response to his summons, it asks for a favor:

8 The character of the professor alludes to Cesare Lombroso, a renowned professor of psychiatry at the University of Pavia from 1862 and one of the most distinguished representatives of scientific positivism in Italy. 9 We can deduce that it was the year 1866 from a reference to the fact that eleven years have passed by the anatomy lesson the character took in Pavia in 1855 .
"Sono a voi. Mi avete chiamato in un momento in cui delle invocazioni più esigenti mi impedivano di venire [...] Nondimeno vi ho obbedito per compiacervi, e perché aveva bisogno io stesso di voi; ed era gran tempo che cercava il mezzo di mettermi in comunicazione con il vostro spirito". (p. 67). This is an example of the classic scheme in which a tormented ghost appears before a living person to solve a problem and assure its eternal rest. The professor's spirit makes the protagonist promise to return the bone (the kneecap) to its rightful owner and tells him that a spirit will visit him that very night to claim it. In the first part of the story, Tarchetti's choice of specific character types (the young apprentice artist, the professor of anatomy and the hypnotist), as well as situations typical of a certain historical epoch, permit him to introduce the deep issues that underlie the story and that are closely linked to the ideological and subcultural climate of the time. The first spirit is invoked through Animal Magnetism, a type of experiment that, as we mentioned before, the author himself conducted, based on the theories developed by the Austrian physician Mesmer on hypnosis and paranormal activities of the psyche. Through the emblematic value of the characters as well as the séance described, science and pseudoscience merge inside a ghost story. Indeed, Tarchetti openly mentions in the text the description of the séance, the hypnotic state of the main character and the automatic writing. It is important to recall the close familiarity of Tarchetti to Mesmerism and Spiritism doctrines of his time.

The second ghost visiting the main character is that of Pietro Mariani, a concierge at the University of Milan, from whose body the professor had stolen the bone he gave to the hero to use as a model for his sketches. In the second part of the story, the spirit of Mariani appears when the protagonist falls asleep after returning home drunk. Following Gautier's ghost story, here the dream phase functions as a transition, a bridge across which the realm of extra-human reality enters that of human reality. By a kind of psychoanalytic intuition, it is considered a phase in which human beings are freed from the rational ties imposed on the mind during its waking hours. Moreover, in the ending part of the story Tarchetti maintains Gautier's scheme, who in turn reproduces a typical topic of the fantastic mode, that is the rationalization of a fantastic (or, in our case, paranormal) event. Upon waking up in the morning, the protagonist believes that the spirit's appearance was only a dream, until he realizes that the bone has disappeared and a black ribbon has been left in its place, the same ribbon the ghost used to hold together the bones of its leg: "Ma quale fu il mio terrore quando vi vidi sparita la rotella, e al suo posto trovai il nastro nero che vi aveva lasciato Pietro Mariani!" (p. 72). The black ribbon demonstrates the reality of the narrated event. As Gautier, Tarchetti employs a device, called by Lugnani [29] "oggetto mediatore di verità", to make the reader believe what is being told him. Tarchetti's stylistic and 
compositional strategy, which is based on a series of characters and objects, creates a narrative structure through which, as Vincenzo Moretti [2] suggests, "un dato psicologico, la credenza nell'aldilà, si trasforma nella presenza del fantasma" (p. 26). Moreover, we can assert that dream, like hypnosis, are functional to the artistic representation of the subject's altered perception of reality. Tarchetti's stylistic and narrative innovation attempts to reproduce a vision of reality based on the pseudoscientific premises of Spiritism, which results in the mediation or fusion between the material and the spiritual via the first-person narrator. What the story suggests is that the inner self is the origin of any apparent or truly mysterious phenomenon. In the first apparition, the protagonist describes the effects that the spirit's presence had on him and the control he exerts over his own body. As in a case of schizophrenia, his hand moves by a force that is alien to his own will: "Dopo alcuni minuti d'indugio mi accorsi per sensazioni nuove e inesplicabili che io non era più solo nella stanza, sentii per così dire la sua presenza; e prima che avessi saputo risolvermi a formulare una domanda, la mia mano agitata e convulsa, mossa come da una forza estranea alla mia volontà, scrisse, me inconsapevole, queste parole" (p. 67). Similar effects can be found in the passage in which the spirit's second appearance is described. The protagonist tells the reader that he is seized with a mental and physical paralysis: "Durai non so quanto tempo in quello stato: io non poteva distogliere la mia attenzione da quella rotella. I miei sensi, le mie facoltà, le mie idee, tutto era concentrato in quella vista, tutto mi attraeva a lei; io voleva sollevarmi, discendere dal letto, uscire, ma non mi era possibile; e la mia desolazione era giunta a tal grado che quasi non ebbi a provare alcun spavento" (p. 70). The suspicion that the protagonist may be suffering from a mental disorder is raised by the protagonist himself. Prey to a profound terror, he finds comfort in drinking before returning home: "Ad ogni bicchiere bevuto il mio timore svaniva sensibilmente, $\mathrm{i}$ miei pensieri si dilucidavano, le mie idee parevano riordinarsi, quantunque con un disordine nuovo" (p. 69). The altered and delusional perception of the first-person narrator guides the discourse. Like a dream or hypnosis, the schizophrenic dissociation of his personality, though transient, alters his perception (and representation) of the space-time dimension of reality. ${ }^{10}$ At this regard, we can state that the diegetic discourse is widely grounded on E.T.A. Hoffmann's Der Sandmann (1817) and Poe's tales.

Apart from that, with regard the changes Tarchetti introduces in Gautier's model, there are some significant alterations to be reckoned with because they give information about the way Tarchetti reuses the model in his

10 From this perspective see the study of four Tarchetti's fantastic stories in Matthew Reza, "The Double Within: Coexistent Minds and the Fantastic in Ugo Tarchetti", Journal Romance Studies, vol. 36, 2018 , 167-179. See also Vittorio Roda, Homo duplex: scomposizioni dell'io nella letteratura italiana moderna, Il Mulino, Bologna, 1991. narrative experimentation. Vincenzo Moretti [2] observed that: "ci sono indubbie analogie: l'insolito oggetto usato da fermacarte, l'episodio dell'ubriachezza, l'apparizione oltremondana ritenuta un sogno e rivelatasi reale in seguito alla presenza di un oggetto lasciato dal fantasma. Ma in Tarchetti vi è una sistematica parodizzazione del modello: il piede dell'imperiale fanciulla mummificata diventa la volgare rotula di un inserviente dell'Università di Pavia; il narratore di Gautier si ubriaca di champagne durante un'elegante cena fra amici, il personaggio tarchettiano invece beve "vini nazionali", da solo, in una brutta osteria; l'uno si ritrova nella sua casa ricca di addobbi preziosi ed eccentrici, l'altro nella squallida camera d'affitto: al gusto preparnassiano del Gautier si oppone il solido realismo lombardo del Tarchetti" (p. 20). We can observe that he enhances the subtle irony underneath the French story, thereby parodying it, with results that sometimes border on the grotesque. The author presents a narration garnished with a large number of gothic motifs: a séance, contacts with a strange presence, voices, the grim stroke of midnight, premonitions, the sense of dread that pervades the hero, nightmares and a ghostly apparition covered by a white sheet. If this pastiche of situations were not enough, the macabre elements, or those that pretend to be so, fail to create an atmosphere of tension and terror, as they are tempered by a heavy dose of irony. Besides, Tarchetti seeks to undercut the staple pathos of ghost stories (traditionally achieved by evoking the sense of fear that precedes and accompanies an actual paranormal event) with ironic and even humorous effects. The first example of it can be found in the manifestation of Professor Federico's spirit, whose initially arrogant words produce a ridiculous effect: "Sono a voi. Mi avete chiamato in un momento in cui delle invocazioni più esigenti mi impedivano di venire" (p. 67), and later, in the mixture of pathetic and comic tones with which the protagonist reacts to the announcement of the spirit's nocturnal visit: "annichilito da quella notizia, coperto di un sudore cadaverico, io mi affrettai ad esclamare, mutando tuono di voce ad un tratto: "Per carità... vi scongiuro... non vi disturbate... manderò io stesso... vi saranno altri mezzi meno incomodi..." (p. 68). Nor less humoristic is the dialogue between the ghost of the servant and the protagonist. When the spirit appears at the home of the man to demand he returns his kneecap, the scene ends up being highly formulaic, mimetic and oddly reassuring: "Avanzatosi fino alla metà della stanza, s'inchinò cortesemente e mi disse: "Io sono Pietro Mariani, e vengo a riprendere, come vi ho promesso la mia rotella". E poiché il terrore mi rendeva esitante a rispondergli, egli continuò con dolcezza: "Perdonerete se ho dovuto disturbarvi nel colmo della notte... in quest'ora... capisco che la è un'ora incomoda... ma...". "Oh! È nulla, è nulla”, io interruppi rassicurato da tanta cortesia, io vi debbo anzi ringraziare della vostra visita... io mi terrò sempre onorato di ricevervi nella mia casa..." (p. 70). 
Finally, there is one more difference with The Mummy's Foot that must have been deeply impressive and humorous for a reader used with fantastic and gothic literature of the time. We refer to the fact that Tarchetti replaces Gautier's young and gorgeous Egyptian princess, Hermonthis, with the phantom of an old and humble servant covered with a white sheet. Furthermore, this change acquires an unquestionable relevance if we take into consideration, with Mariella Muscariello [30], "il gioco letterario a riscrivere umoristicamente le idee tarchettiane in materia di politica, di società e di letteratura" (pp. 247-248). In $A$ Dead Man's Bone, a ghost of a servant going back to haunt an intellectual and a member of middle class living in Milan turns out to be a figure which conveys a critic of the politic and social order established soon after the Unification. To understand the historical message behind it, the article by Teofilo Coreni, entitled "Spiritism and Materialism" (1864) should be recalled here. He states that: "lo spiritismo deve affrettare la riforma sociale [...] mediante la carità fraternale" 11 thus revealing the middle class mindset ambivalence with respect to the 'social question'. The middle class and intellectuals were concerned with it, but at the same time, they were alarmed by the possibility of a radical upheaval. The encounters between the main character and the ghost of Pietro Mariani could be clearly interpreted as a metaphor of it. But not only. On this point, it is due to underline with Andrew Smith [31] that: "Ghost are historical beings because they are messengers about the preoccupations of a particular age" (p. 153). As a consequence, it can be pointed out that Gothic with its instances of social subversion embodied in the ghost, as we can see in A Dead Man's Bone, but also in the already referred $A$ Spirit in a Raspberry and The Legends of the Black Castle, allows Tarchetti to recount the failure of the democratic ideology during the Risorgimento.

In order to focus on this interpretative line, it is worthwhile to examine the sequence relating the visiting of the phantom. As in Gautier's text, the apparition of the spirit in the protagonist's house is preceded by an intense smoke from a candle becoming as thick as lead. Tarchetti added to this supernatural phenomenon much more paranormal elements: "l'atmosfera della stanza, divenuta ad un tratto soffocante, era impregnata di un odore simile a quello che esala dalla carne viva abbrustolita, le mie orecchie erano assordate da un brontolio incessante di cui non sapeva indovinare le cause, e la rotella che vedeva lì, tra le mie carte, pareva muoversi e girare sulla superficie del tavolo, come in preda a convulsioni strane e violente" (p. 70). The addition with respect to Gautier's sequence is an enumeration rethorically meant to reproduce the pshychological paroxysm reached by the character. It also seems to suggest the experience that the author as a soldier was probably faced with firsthand. The interpolation of the autobiographical memory could refer to the third war of

11 Quotation from Moretti [2] p. 21. indipendence, which conflagrated in 1866. This interpretation is reiterated at the end of the story. As in Gautier, the protagonist is awaken by the sensation of the princess's fingers pressing his arm, Tarchetti's protagonist is also awaken by a sound so loud and powerful as that of a cannon: "s'inchinò la terza volta per salutarmi; e quando fu sulla soglia dell'uscio, rispose chiudendone l'imposta dietro di sé: "Sentite se le altre mie ossa non sono più solide". E pronunciando queste parole percosse il pavimento col piede con tanta violenza che le pareti ne tremarono tutte; e a quel rumore mi scossi e... mi svegliai" (p. 71). We can also read this sequence as a methapor of the social and political disillusionment of democratic side of Italian Risorgimento which has its roots, among other things, in the humiliating defeats in the Custoza and Lissa in war of 1866. As a matter of fact the army's defeats display a poor leardership of Italy's collective force under a single government and flag. ${ }^{12}$ In this line, we finally could interpret the black ribbon that the ghost of Pietro Mariani leaves on table to turn true the protagonist's nightmare, as the term of that historical disappointment. The rethorical shift might be demostrate, just by means of the use of a same word, if we quote from the letter that Cattaneo [32], a democratic representative of Risorgimento, writes to the senator Musio on the $9^{\text {th }}$ October 1866: "Ormai, nella memoria della nazione e delle nazioni - e nella coscienza del soldato - Custoza e Lissa sono parti d'un reato solo. Nessuno ha ormai forza di sciogliere quel nodo" (pp. 425-426).

\section{Conclusions}

To conclude, we can say that A Dead Man's Bone is not an exceptional story in terms of the phenomenology of the ghostly apparitions, but rather in terms of the function the scapigliato writer attributes to gothic popular culture and the unprecedented rhetorical strategy he uses. Moreover, this thematic element, which is framed in a positivist discourse, is used to represent a subjective reality and the image of a disturbed self. The complex historical situation is translated into a narration structured around the main character's altered perception of space and time, representing a disempowered and disjoined subjectivity facing a hard reality. As Paccagnini [33] states: "la volontà di denuncia porta sempre più rapidamente Tarchetti a sviluppare la via dell'alterità rispetto al reale" (p. 303). As we have previously explained, the rewriting or use of fantastic mode and gothic conventions allows Tarchetti to experiment in narration forms that are meant to be realistic in a new way, opposite to traditional precepts. ${ }^{13}$ Hence, as

12 Between November 1866 and March 1867, Tarchetti published in $\mathrm{Il}$ Sole, the anti-militaristic pamphlet novel Una nobile follia (Drammi della vita militare).

13 To do this, it is important to stress the Tarchetti's use of fantastic and gothic. It is clear that the author ought to guess, as Ceserani [6] points out, 
mentioned above, the specific elements of Tarchetti's fantastic narratives, as well as the use of ghostly apparitions, underline the need to examine not so much the models and norms of this subgenre, but the meanings his work acquires in the process of synchronization and integration in a specific historical and cultural moment, and the urgency to renew the fantastic in a stylistic and compositional rather than a thematic mode. It is an experiment whose aim is to programmatically search for an alternative realism; not so much in terms of the object that is represented, but rather of the representative modes that are adopted to provide a vision of a world in constant change between the true and the possible, the rational and the irrational. In general, we should not forget that Tarchetti introduced fantastic narrative into the Italian literary scene. This is surely his most remarkable contribution, along with, as Pieri [27] asserts, the experimental ardor by which he subverted "la tradizione del fantastico con una invenzione formale che non avrà emulatori" (p. 120). Lastly, the significance and ultimate value of the initial and uncertain fruits of this process of adaptation can only be properly discerned by examining Tarchetti's work from historical, cultural and narratological perspectives.

\section{REFERENCES}

[1] I. U. Tarchetti. Racconti fantastici, in Tutte le opere, vol. II, ed. E. Ghidetti, Cappelli Editore, Bologna, 1967. All quotations are taken by this edition. See also English translation: I. U. Tarchetti, Fantastic Tales, trans. and ed. by L. Venuti, Mercury House, San Francisco, 1992.

[2] V. Moretti. "Igino Ugo Tarchetti e il racconto fantastico", in Scapigliatura e dintorni. Ottocentisti minori e minimi verso il Novecento, Lampi di stampa, Milano, 2005, 17-30. Before in AA.VV., Igino Ugo Tarchetti e la Scapigliatura. Atti del Convegno (S. Salvatore Monferrato, 1-3 ottobre 1976), Comune di S. Salvatore Monferrato and Cassa di Risparmio di Alessandria, 1979, 103-11.

[3] N. Bonifazi. Teoria del fantastico e il racconto fantastico in Italia: Tarchetti-Pirandello-Buzzati, Longo, Ravenna, 1982.

[4] L. Venuti. Introduction to his translation Fantastic Tales by Igino Ugo Tarchetti, Fantastic Tales, trans. and ed. by L. Venuti, Mercury House, San Francisco, 1992.

[5] G. Mariani. "Il racconto come storia delle sensazioni: Igino Ugo Tarchetti" in Storia della Scapigliatura, Sciascia, Caltanisetta-Roma, 1967, 369-472.

that it is "a literary mode which has been produced, [and] has been employed, in a particular historical juncture to expand and broaden the array of internal and external psychological 'realities' that can be represented through literary language. Furthermore, it has challenged the relations that, in every historical period, can be constructed between the paradigm of reality, language ant their mutual strategies of representation" (p. 75).
[6] R. Ceserani. Il fantastico, il Mulino, Bologna, 1996.

[7] U. Bosco. "Il Tarchetti e i suoi Racconti fantastici" in Realismo romantico, Sciascia, Caltanissetta-Roma, 1959, 127-137.

[8] E. Ghidetti. Tarchetti e la Scapigliatura lombarda, Libreria scientifica editrice, Napoli, 1968.

[9] F. Moretti. Atlante del romanzo europeo (1800-1900), Einaudi, Torino, 1997.

[10] R. Ceserani. "The Boundaries of the Fantastic" in The Italian Gothic and Fantastic: Encounters and Rewritings of Narrative Traditions, eds. F. Billiani, G. Sullis, Fairleigh Dickinson University Press, Madison, NJ, 2007, 37-45.

[11] M. Farnetti. Il giuoco del maligno. Il racconto fantastico nella letteratura italiana tra Otto e Novecento, Vallecchi, Firenze, 1988.

[12] G. Desideri. "Il fantastico" in Letteratura Italiana, vol. III, Storia e geografia, , ed. by A.Asor Rosa, Einaudi, Torino, 1989, 969-998.

[13] L. Lugnani. "Per una delimitazione del genere" in $L a$ narrazione fantastica, eds. R. Ceserani, L. Lugnani, G. Goggi, C. Benedetti, E. Scarano, Nistri-Lischi, Pisa, 1983, 37-73.

[14] F. Billiani. "The Italian Gothic and Fantastic: An Inquiry into the Notions of Literary and Cultural Traditions (1869-1997)" in The Italian Gothic and Fantastic: Encounters and Rewritings of Narrative Traditions, eds. F. Billiani, G. Sullis, Madison, NJ, Fairleigh Dickinson University Press, 2007, 15-31.

[15] F. Billiani. "Il testo fantasticizzato e goticizzato come metafora della destrutturazione del discorso 'nazione': attorno agli scrittori scapigliati”, California Studies, Vol. 2, No.1, 2011. Accessed January 2020. https://escholarship.org/uc/item/5zt6q9nm

[16] G. Tellini. Il romanzo italiano dell'Ottocento e Novecento, Mondadori, Milano, 1998.

[17] G. Lo Castro. "Introduzione" to La tentazione del fantastico. Racconti italiani da Gualdo a Svevo, eds. A. D'Elia, A. Guarnieri, M. Lanzillotta, G. Lo Castro, Luigi Pellegrini Editore, Cosenza, 2007.

[18] F. Amigoni. Fantasmi nel Novecento, Bollati Boringhieri, Torino, 2004.

[19] C. Gallini. "I territori del meraviglioso" in Linguaggio, ragione, follia, ed. R. Beneduce, ESI, Napoli, 1990, 193-212.

[20] S. Cigliana. La seduta spiritica. Dove si racconta come e perché i fantasmi hanno invaso la modernità, Fazi, Roma, 2007.

[21] I. U. Tarchetti. Riccardo Waitzen, in Tutte le opere, vol. I, ed. E. Ghidetti, Cappelli Editore, Bologna, 1967.

[22] S. Farina. "Ritratto di Iginio Ugo Tarchetti", in Racconti neri della scapigliatura, ed. G. Finzi, Mondadori, Milano, 1980 , 161-163.

[23] G. Rosa. La narrativa degli scapigliati, Laterza, Bari-Roma, 1997. 
[24] P. Pieri. "Introduzione" to I. U. Tarchetti, Racconti fantastici, eds. P. Pieri, N. D’Antuono, Millennium, Bologna, 2003.

[25] E. Scarano. "I modi dell'autenticazione", in La narrazione fantastica. Le radici storiche di un modo narrativo, eds. $\mathrm{R}$. Ceserani et al., Nistri-Lischi, Pisa, 1983, 355-396.

[26] A. Mangini. La voluttà crudele. Fantastico e malinconia nell'opera di Tarchetti, Carocci, Roma, 2000.

[27] P. Pieri. "Il fantastico di Tarchetti tra realismo autobiografico e verismo stilistico", in Il visionario, il fantastico, il misterioso tra Otto e Novecento, eds. A. M. Mangini - L. Weber, Allori, Ravenna, 2006, 99-134.

[28] T. Gautier. Racconti fantastici, ed. R. Ceserani, Mondadori, Milano, 1991.

[29] L. Lugnani. "Verità e disordine: il dispositivo dell'oggetto mediatore" in La narrazione fantastica, eds. R. Ceserani, L. Lugnani, G. Goggi, C. Benedetti, E. Scarano, Nistri-Lischi, Pisa, 1983, 177-288.

[30] M. Muscariello. "L’umorismo di I.U. Tarchetti, ovvero la passione delle opinioni" in AA. VV. Effetto Sterne. La narrazione umoristica in Italia da Foscolo a Pirandello, Nistri-Lischi, Firenze, 1990, 231-263.

[31] A. Smith. "Hauntings" in The Routledge Companion to Gothhic, ed. by C. Spooner and E. McEvoy, Routdledge, London-New York, 2007, 147-154.

[32] C. Cattaneo. Epistolario, vol. IV, Opere scelte, Einaudi, Torino, 1972.

[33] E. Paccagnini. "Dal Romanticismo al Decadentismo. La Scapigliatura" in Tra l'Otto e il Novecento, vol. VIII, Storia della Letteratura Italiana, ed. E. Malato, Salerno Editrice, Roma, 1999, 263-337. 